\title{
Description
}

\section{'Florida Blue' Semi-dwarf Lisianthus [Eustoma grandiflorum (Raf.) Shinn.]}

\author{
Brent K. Harbaugh and John W. Scott \\ Gulf Coast Research and Education Center, University of Florida, 5007 60th \\ Street East, Bradenton, FL 34203
}

\section{David B. Rubino}

U.S. Department of Agriculture, Agricultural Research Service, Florist and Nursery Crops Laboratory, Beltsville, MD 20705

Additional index words. heat tolerant, high temperature, rosette

Lisianthus was introduced into the U.S. floricultural trade in the early 1980s. Although evaluated as a potential cut flower and potted plant (Halevy and Kofranek, 1984), introduced cultivars primarily were developed for use as cut flowers. They required high rates of plant growth retardants to make them suitable as potted plants (Starman, 1991; Tjia and Sheehan, 1986; Whipker et al., 1994). In the early 1990s, the dwarf cultivars Little Belle Blue, Blue Lisa, and Mermaid Blue were released to U.S. markets. These dwarf cultivars can be grown as potted plants without growth retardants.

Although breeding efforts were successful in developing shorter plants, problems with heat-induced rosetting were similar to those with taller cultivars. Dwarf cultivars also rosette when grown at 25 to $28^{\circ} \mathrm{C}$ (Harbaugh et al., 1992; Ohkawa et al., 1991). Rosetted plants have a basal cluster of leaves and very short internodes typical of biennials, and they do not bolt or flower for 3 to 6 months without exposure at $\leq 18^{\circ} \mathrm{C}$ for 3 to 4 weeks to reverse heatinduced rosetting (Ohkawa et al., 1994; Pergola, 1992). Semirosetted plants develop when seedlings are grown at a constant 22 to $25^{\circ} \mathrm{C}$ or at $<22{ }^{\circ} \mathrm{C}$ nights with $>28{ }^{\circ} \mathrm{C}$ days. Semirosetted plants have one or more side shoots that may elongate and flower, but plants flower unpredictably and are of poor quality. Thus, commercial production of lisianthus for late spring or summer sales as cut flowers or as potted plants is limited by high temperatures in many areas of the United States and other countries. Fall plug production, to produce flowering plants for early spring sales, is also impossible due to rosetting of plugs caused by the interaction of high temperatures and short days (Harbaugh, 1995). 'Florida Blue' is a heat-tolerant, semi-dwarf lisianthus developed at the Univ. of Florida's Gulf Coast Research and Education Center, Bradenton. Seedlings have been produced at 28 to $31{ }^{\circ} \mathrm{C}$ without rosetting.

Received for publication 17 Nov. 1995. Accepted for publication 18 June 1996. Florida Agricultural Experiment Station Journal series R-04860. We thank Nancy West for her excellent technical support. The cost of publishing this paper was defrayed in part by the payment of page charges. Under postal regulations, this paper therefore must be hereby marked advertisement solely to indicate this fact.

\section{Origin}

'Florida Blue' is the $F_{1}$ hybrid resulting GCREC-34 (Fig. 1). GCREC-46 was an $\mathrm{F}_{4}$ selection of a cross between GCREC-8-21 and 'Mermaid Blue'. GCREC-34 was an $\mathrm{F}_{4}$ selection of a cross between GCREC-9-105 and 'Blue Lisa'. 'Mermaid Blue' and 'Blue Lisa' were used for their dwarf characteristics. GCREC-8-21 and GCREC-9-105 were identified after three generations of selfpollination $\left(\mathrm{S}_{3}\right)$ from 'Blue Poppy'. They were selected for their ability to flower at high temperatures $\left(35^{\circ} \mathrm{C}\right.$ day), their basal branching characteristics (i.e., lateral stems forming from the first four to five leaf pairs before bolting), and lower branching characteristics (i.e., lateral stems forming on the central flowering stem before the first flower bud). Growing conditions used to select $F_{1}$ to $F_{4}$ GCREC46 and GCREC-34 lines for resistance to heatinduced rosetting were 1) exposure of 3- to 4week-old $\mathrm{F}_{1}$ to $\mathrm{F}_{3}$ seedlings to $28{ }^{\circ} \mathrm{C}$ for 4 weeks and 2) exposure of 17-day-old $\mathrm{F}_{4}$ seedfrom the cross of inbred lines GCREC-46 and lings to $31^{\circ} \mathrm{C}$ for 5 weeks.

Seventeen-day-old 'Florida Blue' seedlings exposed to constant $31^{\circ} \mathrm{C}$ for 5 weeks did not develop rosetted plants (Table 1). In contrast, similar treatment of 'Blue Lisa', 'Mermaid Blue', and 'Little Belle Blue' resulted in 100\% semirosetted or rosetted plants. 'Florida Blue' plants grown in $11.5-\mathrm{cm}$ square pots $(0.65-\mathrm{L})$ with capillary mat irrigation were similar in height to 'Blue Lisa' and taller than 'Little Belle Blue' and 'Mermaid Blue'. 'Florida Blue' had 4.4 basal breaks and 3.0 lower breaks. This combination of basal and lower branching characteristics resulted in a higher flower and bud count than the dwarf cultivars examined. There were 142 days from a 20 Dec. sowing to first open flower for 'Florida Blue'. Days-to-flower for 'Florida Blue' appears similar to those for 'Little Belle Blue' and 'Mermaid Blue', but 11 days more than for 'Blue Lisa'. The range in days-to-flower in other 'Florida Blue' trials during 1995-96 was 107 days (1 Aug. sowing) to 147 days (15 Nov. sowing).

Open flowers of 'Florida Blue' are bellshaped with a petal length of $5.1 \pm 0.1 \mathrm{~cm}$. When first opened, flower petals are a violet blue [Royal Horticultural Society (RHS) violet-blue group 90C; RHS, 1966] on the adaxial petal surface diffusing to a variegated $1.8 \pm$ 0.2 -cm white band (RHS white group 155C) at the base of the petals. As the flower matures, the petal color darkens to dark purple (RHS dark purple group 79A) and the white band fades or completely disappears. The abaxial petal surface is a lighter violet (RHS violetblue group 90D) while opening and then darkens to purple as the flower matures (RHS violet-blue group 86B). The center of the flowers (i.e., the base of the petals surrounding the ovary) is a dark purple (RHS purple group 79A).

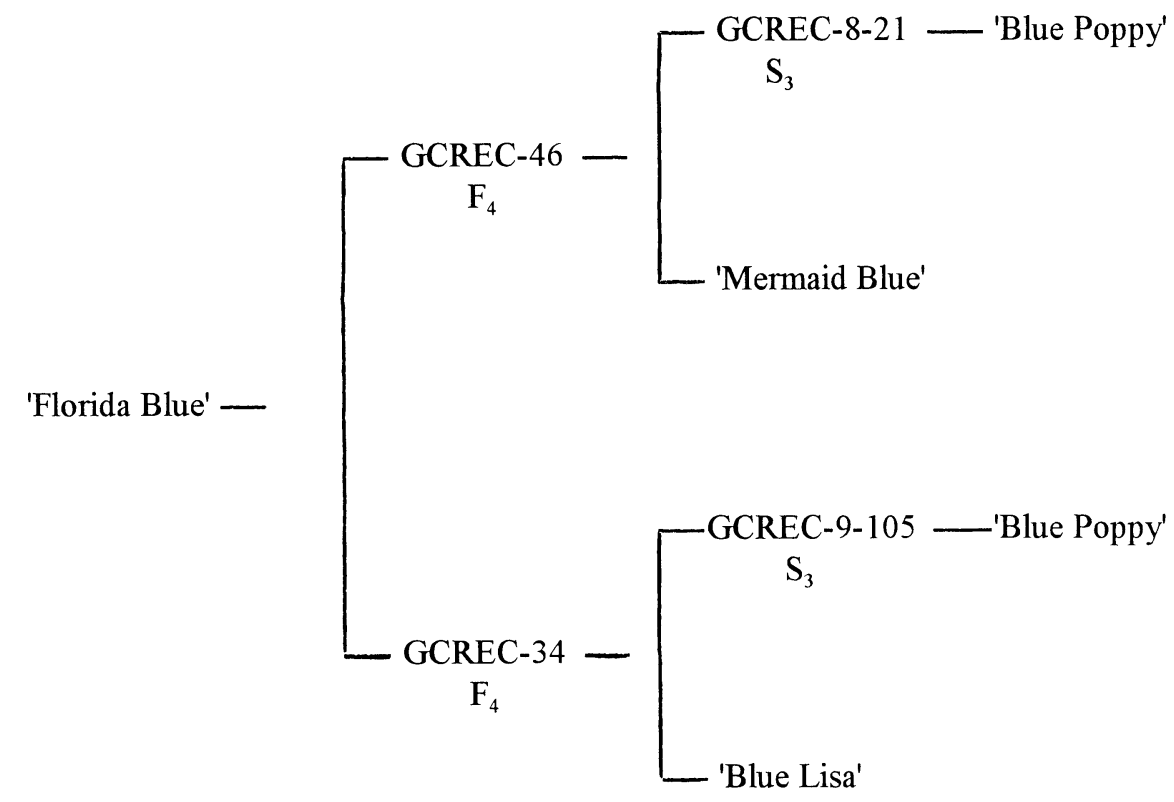

Fig. 1. Pedigree of 'Florida Blue' semi-dwarf lisianthus. 
Table 1. Rosetting percentages of lisianthus cultivars after exposure of seedlings to greenhouse or high temperatures, ${ }^{\mathrm{z}}$ and vegetative and flowering characteristics of lisianthus cultivars sown on 20 Dec. and produced in $11.5-\mathrm{cm}$ square pots $(0.65-\mathrm{L})$ with capillary mat irrigation.

\begin{tabular}{|c|c|c|c|c|c|c|c|c|}
\hline \multirow[b]{3}{*}{ Cultivar } & \multirow{2}{*}{\multicolumn{2}{|c|}{ Rosetted $(\%)^{\mathrm{y}}$}} & \multirow{3}{*}{$\begin{array}{c}\text { Plant } \\
\text { ht } \\
(\mathrm{cm})^{x}\end{array}$} & \multirow{2}{*}{\multicolumn{2}{|c|}{ Breaks (no.) ${ }^{\mathrm{x}}$}} & \multirow{3}{*}{$\begin{array}{c}\text { Flowers } \\
\text { and buds } \\
(\text { no. })^{x}\end{array}$} & \multirow{3}{*}{$\begin{array}{l}\text { Petal } \\
\text { length } \\
(\mathrm{cm})^{\mathrm{x}}\end{array}$} & \multirow{3}{*}{ 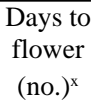 } \\
\hline & & & & & & & & \\
\hline & Control & $31^{\circ} \mathrm{C}$ & & Basal & Lower & & & \\
\hline Florida Blue & 0 & 0 & 38 & 4.4 & 3.0 & 61 & 5.1 & 142 \\
\hline Blue Lisa & 8 & 100 & 32 & 3.0 & 3.4 & 40 & 4.6 & 131 \\
\hline Little Belle Blue & 54 & 100 & 22 & 2.2 & 1.8 & 34 & 4.9 & 143 \\
\hline Mermaid Blue & 21 & 100 & 24 & 6.0 & 1.0 & 47 & 5.0 & 139 \\
\hline $\mathrm{LSD}_{0.05}$ & & & 6 & 1.6 & 2.2 & 14 & 0.5 & 6 \\
\hline
\end{tabular}

${ }^{\mathrm{z}}$ Seedlings were grown in a greenhouse at 28 to $33^{\circ} \mathrm{C}$ day and 13 to $15^{\circ} \mathrm{C}$ night (control), or 17 -day-old seedlings were exposed to $31^{\circ} \mathrm{C}$ for 5 weeks in a growth chamber and then flowered in the greenhouse. y Percentage of rosette or semirosette plants, $n=24$.

${ }^{x}$ Vegetative and flowering characteristics were for nonrosetted control plants. Values represent the means of five replications of single-plant experimental units arranged in a randomized complete-block design.

\section{Characteristics and use}

To our knowledge, 'Florida Blue' is the first heat-tolerant, semi-dwarf lisianthus cultivar. 'Maurine Blue', a tall, heat-tolerant bedding plant or bouquet-cut flower, was released from our lisianthus breeding program in July 1995 (Harbaugh et al., 1996). 'Florida Blue' is intended to be used as a bedding plant and was designated as a semi-dwarf cultivar because production trials have shown that it normally is from 6 to $16 \mathrm{~cm}$ taller than commercial dwarf cultivars and 25 to $45 \mathrm{~cm}$ shorter than cut-flower cultivars. Growth retardants would be useful for production in pots $\leq 10$ to $12 \mathrm{~cm}$ in diameter $(0.5$ to $0.7 \mathrm{~L})$, especially if plants are produced with capillary mat irrigation. The height of 'Florida Blue' was $25 \pm 0.2 \mathrm{~cm}$ following one foliar application of butanedioic acid mono(2,2-dimethylhydrazide) (daminozide) at $5000 \mathrm{mg} \cdot \mathrm{L}^{-1}$ to 5 - to 7 -cm-tall plants grown in $11.5-\mathrm{cm}$ square pots $(0.65-\mathrm{L})$ provided with capillary mat irrigation.

\section{Availability}

Seeds of 'Florida Blue' will be offered for sale through PanAmerican Seed Co., West Chicago, Ill. Scientists interested in seed for research purposes can contact B.K.H.

\section{Literature Cited}

Harbaugh, B.K. 1995. Flowering of Eustoma grandiflorum (Raf.) Shinn. cultivars influenced by photoperiod and temperature. HortScience 30:1375-1377.

Harbaugh, B.K., M.S. Roh, R.H. Lawson, and B. Pemberton. 1992. Rosetting of lisianthus cultivars exposed to high temperatures. HortScience 27:885-887.

Harbaugh, B.K. and J.W. Scott. 1996. 'Maurine Blue' lisianthus [Eustoma grandiflorum (Raf.) Shinn.]. HortScience 31:1055-1056.

Ohkawa, K., A. Kano, K. Kanematsu, and M. Korenaga. 1991. Effects of air temperature and time on rosette formation in seedlings of Eustoma grandiflorum (Raf.) Shinn. Scientia Hort. 48:171-176.

Ohkawa, K., T. Yoshizumi, M. Korenaga, and K. Kanematsu. 1994. Reversal of heat-induced rosetting in Eustoma grandiflorum with low temperatures. HortScience 29:165-166.

Pergola, G. 1992. The need for vernalization in Eustoma russellianum. Scientia Hort. 51:123127.

Royal Horticultural Society. 1966. Royal Horticultural Society colour chart. Royal Hort. Soc., London

Starman, T.W. 1991. Lisianthus growth and flowering responses to uniconazole. HortScience 26:333.

Tjia, B. and T.J. Sheehan. 1986. Chemical height control of Lisianthus russellianus. HortScience 21:147-148.

Whipker, B.E., R.T. Eddy, and P.A. Hammer. 1994. Chemical growth retardant application to lisianthus. HortScience 29:1368. 